\title{
Cognitive, Affective and Behavioral Components That Explain Attitude toward Statistics
}

\author{
Arturo García-Santillán ${ }^{1}$, Elena Moreno-García ${ }^{1}$, Juan Carlos-Castro² ${ }^{2}$ Jorge H. Zamudio-Abdala ${ }^{2}$ \& Julieta \\ Garduño-Trejo ${ }^{2}$
}

${ }^{1}$ Economic-Administrative Research Center, Cristóbal Colón University, Veracruz, México

${ }^{2}$ Second year students Doctoral Program in Management Science at Cristóbal Colón University, Veracruz, México

Correspondence: Arturo García-Santillán, Full Time Researcher, Cristóbal Colón University, Veracruz, México. Tel: 52-229-9232-950-6285. E-mail: agarcias@ucc.mx

Received: July 6, 2012 Accepted: July 22, 2012 Online Published: September 11, 2012

doi:10.5539/jmr.v4n5p8 URL: http://dx.doi.org/10.5539/jmr.v4n5p8

This research was financed by Research Faculty "MATEPEA"

\begin{abstract}
The purpose of this research is to measure the students' attitude towards statistics. It was necessary to define a certain type of research subjects, so we chose higher education students from the economic-administrative and engineering areas that were taking statistics as a subject in both, public and private universities located in Veracruz - Boca del Rio metropolitan area. The instrument used was the Survey of Attitude towards Statistics (SATS), and we applied it to a sample of 116 students. The statistical technique used was an exploratory factorial analysis with an extracted principal component. The Statistics Hypothesis: $H o: \rho=0$ has no correlation, while $H a: \rho \neq 0$ does. Statistics test to prove: $\chi^{2}$, Bartlett's test of sphericity, KMO (Kaiser-Meyer-Olkin), Measure of sampling adequacy (MSA) with a significance level: $\alpha=0.01 ; p<0.01$ Decision rule: Reject Ho if $\chi^{2}$ calculated $>\chi^{2}$ tabulated. The results obtained from the Bartlett's test of sphericity, KMO (0.600), Chi square $\chi^{2} 74.146>\chi^{2}$ tabulated, Sig. $0.00<p 0.01$, MSA (USF 0.673; ANX 0.521; CNF 0.624; LIK 0.613 and MTV 0.523) provide evidence to reject $\mathrm{Ho}$. Global results point out that usefulness and anxiety are the most significant components in measuring students' perception towards statistics. Evidence obtained was enough to reject the null hypothesis, thus we can infer that attitude can be measured based on the cognitive, affective and behavioral components.
\end{abstract}

Keywords: attitude, statistics, cognitive component, affective component, behavioral component

\section{Introduction}

\subsection{Overview Attitude Statistics}

Research on the subject of the attitude towards statistics have gained importance and interest since the seminal work of Wise (1985) and Auzmedi (1991; 1992) who measured attitude from an affective and cognitive point of view. Studies by Gil Flores (1999) and Gómez-Chacón (2000) brought out within the definition given to these preponderant variables called "attitude" three basic factors, also called pedagogical components. The cognitive component, which refers to the mental process of perception, conceptions and beliefs about the attitudinal object, in this case, is pertaining to statistics. The affective or emotional component, which collects all those emotions and feelings that stimulate statistics, for example; those subjective reactions of trust and distrust, like and dislike, among others. Finally, the behavioral component is related to expressions of behavioral intention or action, behavior that represents the tendency to act or resolve in a specific way. Previously, Sheriff, Sheriff \& Neberhall (1965) and Newcomb, Turner and Converse (1965) have focused on measuring the cognitive element by the opinion of the subject. Finally, attitude is determined by three components: cognitive, affective and relative to the conduct (Sheriff et al., 1965; Newcomb et al., 1965; Freedman et al., 1970).

\subsection{About Attitude}

Schau, Stevens, Dauphinee and Del Vecchio (1995) structured attitude into four components or dimensions: affective, related to positive feelings towards statistics; cognitive, as the perception of one's capacity for knowledge and thinking skills in statistics; the value, as the usefulness, the relevance and perceived value of statistics in 
common life, personally and professionally, and finally, the component of difficulty, which focuses on the perception of statistics as a subject, even if the student can recognize its usefulness (component value), and have interest towards it (affective component) and think that they have enough skill and knowledge (cognitive component) and still consider the subject to be easy or difficult.

There are different definitions regarding attitude. To Auzmendi (op. cit.) attitudes "are aspects not directly observable but inferred, comprised of both beliefs as feelings and behavioral predispositions toward the targeted object". Gomez-Chacon (op. cit.) defines attitude as "evaluative bias (negative or positive) that determines the personal and behavioral intention". Gal and Ginsburg (1994) states that attitude is the "sum of all the emotions and feelings experienced during the learning phase of the studied subject". In this work they speak of the attitude assumed by the students about statistics. These studies measure student perceptions based on the following aspects: the affective and cognitive skills of knowledge, evaluation of the matter, the impact of statistics in the student's attitude and the use given to statistics as a tool to solve problems. Earlier research had measured elements that explain the variable "attitude" in the learning process of mathematics in students from different backgrounds and academic levels, all of them, with low positive results towards the perception of mathematics and statistics.

\subsection{Attitude Scale}

The first scale of attitude toward statistics that were used by different authors was the Statistics Attitude Survey (SAS) of Roberts and Bilderback (1980), which was developed to meet the needs to know or measure the attitude of students by statistics teachers. This instrument was adapted from a questionnaire proposed by Dutton (1954) that was designed to measure the attitude towards mathematics, and was regarded as a unidimensional instrument. However, Wise (op. cit.) considered that SAS covered a significant need for the development of a construct, but it was inappropriate for new students or students unfamiliar with statistics, and furthermore, this survey seemed to measure more the academic performance than the attitude towards statistics. This author developed a construct with a different scale: the Attitudes toward Statistics Scale (ATS), with items totally focused to meet the changing attitudes of students in basic statistics. He considered two domains, one measuring the attitude toward the subject and the other measures the attitude towards the use of statistics in their field of study. Later, Auzmendi used the tests described above to measure the attitude of students with different socio-educational characteristics. However, poor implementation of both tests in their field of study led to perform a new measuring instrument that was consistent with their needs, moreover, it most be adequate to its context, considering multidimensional attitudes toward mathematics and statistics, in order to detect the most significant factors.

About statistics in particular, we can say that despite being a useful instrument, there has been some neglect and little interest in the quality of its teaching, which has led to a stigma and misconceptions about it among students (Behar \& Grima, 2001). This phenomenon has been addressed in numerous studies on the attitude and anxiety towards statistics, focusing mainly on university students because this subject is part of many curricula in both careers: exact sciences and the economic-managerial (Dillon, 1982; Cashin \& Elmore, 1997 \& 2000; Cashin, 2001; Carmona, 2004; Watson, Kromrey, Ferron, Lang, \& Hogarty, 2003; Onwuegbuzie, DaRos, \& Ryan, 1997; Onwuegbuzie, 1998 \& 2003; Onwuegbuzie \& Daley, 1999; Onwuegbuzie \& Wilson, 2003; Nasser, 2004) among others.

The issue of attitude towards statistics has been approached from different perspectives ranging from the teaching methodology, changes in curricula, teacher training, to study habits (Bishop, 1996; Onwuegbuzie, Slate, Paterson, Watson, \& Schwartz, 2000). The study of the relationship between attitude, learning and academic performance has been reviewed internationally in numerous studies (Aparicio \& Bazan, 1997; Aparicio \& Bazan, 2006 \& 2008), which reveal that students' attitudes towards statistics is low and does not differ by gender, but it does by age and specialist field.

\subsection{Attitude as a Main Element in the Teaching - Learning Process}

The attitude is essential to carry out the teaching-learning process. Different studies show that its development is important to teach and learn any subject (Gómez-Chacón, op. cit.). Other research such as Phillips (1993) and Agne, Greenwood and Miller (1994) prove that the relationship between attitudes and beliefs of the teacher as well as performance, beliefs and attitudes of students are either positively or negatively, depending on the predisposition they both have - teacher and student - towards the subject.

If the attitude is encouraged and programs are based on activities that seek to develop math skills, arouse curiosity, stimulate imagination and provide opportunities for student development, ensuring a solid foundation to promote knowledge and development of the student (Aparicio \& Bazan, 2006). Even Eagly and Chaiken (1998) have con- 
ceptually referred to attitude as a psychological tendency expressed in a particularly way - favorable or unfavorable - at any given level.

In the case of mathematics and statistics, the attitude is a trend that is formed over time as a result of emotions and feelings experienced in the teaching-learning process (Gal, Ginsburg, \& Schau, 1997). Although there is sufficient empirical evidence on the importance of attitude of students and their relation to learning and academic performance, there is a lack of models that can locate the proper attitude and consider relevant factors such as liking, trust, usefulness, motivation and anxiety. Thus, the objective of this research is to determine if there is a set of variables that form a structure to understand the perception of students towards statistics.

\section{Method}

\subsection{Population and Instrument}

Population was selected by non-probability sampling trial and the choice of subjects did not depend on the probability, but of the causes associated with the characteristics of the research and the sample consisted of 116 undergraduate and postgraduate students of the following universities: Centro Universitario Hispano Mexicano (CUHM), Instituto Tecnológico de Veracruz (ITV) y Escuela Superior de Negocios (ESUN).

The selection criteria was to include students who have already completed at least one field of statistics in the undergraduate or graduate program who were studying and that were available in the institution when applying the survey. We applied a questionnaire "Scale of attitudes toward statistics" (SATA) of Auzmendi (1992) with 25 items on a Likert scale ranging from strongly disagree (1) to strongly agree (5). The results of the pilot test indicated the need to redefine the indicators according with the population's context; therefore, we used the "criteria of judges' technique."

Questionnaire was analyzed from the perspective of seven judges, professors all of them, that in their training and professional activity have been studied and employed statistics as an analysis tool. These professors' chose the code that was associated to each of the 25 survey items. The factors, codes and definitions are presented in Table I. Table II shows the items that changed from the original scale, derivated of the results that the judges made of the items of survey proposed by Auzmendi (1992). Finally in order to check the coefficient's reliability, Cronbach's alpha was applied for testing several alternatives, until reaching a value of 0.670 .

Table 1. Factors associated with student attitude towards learning statistics

\begin{tabular}{lll}
\hline Indicators & Definition & Code \\
\hline $\begin{array}{l}\text { Likeness } \\
\text { Anxiety }\end{array}$ & $\begin{array}{l}\text { Refers to the liking of working with statistics. } \\
\text { Can be understood as the fear the students man- }\end{array}$ & $\begin{array}{l}\text { LIK } \\
\text { ifests towards statistics. }\end{array}$ \\
Confidence & $\begin{array}{l}\text { Can be interpreted as the feeling of confidence } \\
\text { of the skill in statistics. }\end{array}$ & CNF \\
Motivation & $\begin{array}{l}\text { What the student feels towards the studying and } \\
\text { usefulness of statistics. }\end{array}$ & MTV \\
Usefulness & $\begin{array}{l}\text { It is related to the value that a student's gives } \\
\text { statistics for its professional future. }\end{array}$ & USF \\
\hline
\end{tabular}

Table 2. Set item modificated from its original scale

\begin{tabular}{lll}
\hline Item & Auzmendi's Test & Reclasification \\
\hline 5 & USF & MTV \\
10 & USF & MTV \\
15 & ANX & MTV \\
19 & USF & LIK \\
20 & LIK & USF \\
24 & MTV & LIK \\
25 & USF & MTV \\
\hline
\end{tabular}

\subsection{Procedure}

In order to measure the data collected from students and test the hypothesis $(\mathrm{Ho})$ about a set of variables that form 
the construct for understanding the perception of students towards statistics, we considered the follow Hypothesis: Ho: $\rho=0$ have no corelation $\mathrm{Ha}: \rho \neq 0$ have correlation.

Test statistic to prove: $\chi^{2}$, and Bartlett's test of sphericity, KMO (Kaiser-Meyer-Olkin), MSA (Measure of sampling adequacy), significancy level: $\alpha=0.01 ; p<0.01$ load factorial of .70 Critic value: $\chi^{2}$ calculated $>\chi^{2}$ tabulated, then reject $H o$ and the decision rule is: Reject $H o$ if $\chi^{2}$ calculated $>\chi^{2}$ tabulated.

The statistical procedure to measure data is an exploratory Factorial Analyze Model; therefore it was taken the procedure proposed by García-Santillán et al. (2012) and obtains the following matrix:

\begin{tabular}{ll}
\hline Students & Variables $X_{1} X_{2} \ldots X_{p}$ \\
\hline 1 & $X_{11} X_{12} \ldots x_{1 p}$ \\
2 & $X_{21} X_{22} \ldots x_{2 p}$ \\
$\cdots$ & $\ldots$ \\
116 & $X_{n 1} X_{n 2} \ldots x_{n p}$ \\
\hline
\end{tabular}

The above is given by the following equation:

$$
\begin{aligned}
& \mathrm{X}_{1}=\mathrm{a}_{11} \mathrm{~F}_{1}+\mathrm{a}_{12} \mathrm{~F}_{2}+\cdots+\mathrm{a}_{1 \mathrm{k}} \mathrm{F}_{\mathrm{k}}+\mathrm{u}_{1} \\
& \mathrm{X}_{2}=\mathrm{a}_{21} \mathrm{~F}_{1}+\mathrm{a}_{22} \mathrm{~F}_{2}+\cdots+\mathrm{a}_{2 \mathrm{k}} \mathrm{F}_{\mathrm{k}}+\mathrm{u}_{2} \\
& \cdots \cdots \\
& \mathrm{X}_{\mathrm{p}}=\mathrm{a}_{\mathrm{p} 1} \mathrm{~F}_{1}+\mathrm{a}_{\mathrm{p} 2} \mathrm{~F}_{2}+\cdots+\mathrm{a}_{\mathrm{pk}} \mathrm{F}_{\mathrm{k}}+\mathrm{u}_{\mathrm{p}}
\end{aligned}
$$

Where $F_{1}, \ldots, F_{k}(K<p)$ are common factors, $u_{1}, \ldots, u_{p}$ are specific factors and the coefficients $\{a ; i=1, \ldots, p$; $j=1, \ldots, k\}$ are the factorial load. It is assumed that the common factors have been standardized or normalized $E\left(F_{i}\right)=0, \operatorname{Var}\left(f_{i}\right)=1$, the specific factors have a mean equal to zero and both factors have correlation $\operatorname{Cov}\left(F_{i}, u_{j}\right)=0, \forall i=1, \ldots, k ; j=1, \ldots, p$.

With the following consideration: if they are correlated, it must be $\operatorname{cov}\left(F_{i}, F_{j}\right) 0$, if $\left.i \neq j ; j, i=1, \ldots, k\right)$ then we are dealing with a model with orthogonal factors, if not correlated, it is a model with oblique factors. Therefore, the equation can be expressed as follows:

$$
x=A f+u=F A^{\prime}+U
$$

Where:

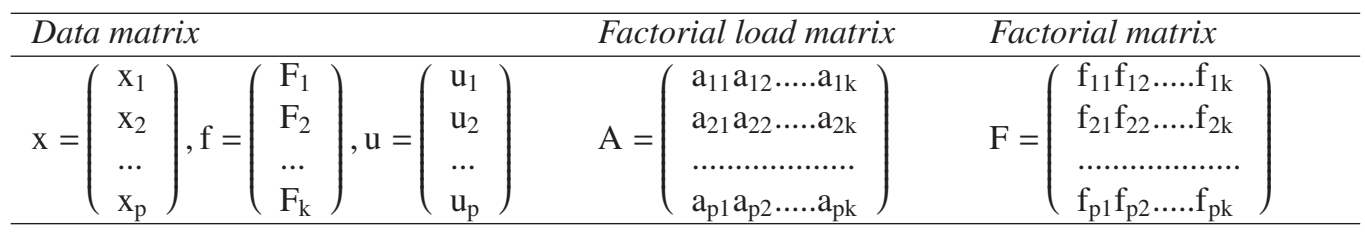

With a variance equal to:

$$
\operatorname{Var}\left(X_{i}\right)=\sum_{j=1}^{k} a_{i j}^{2}+\psi=h_{i}^{2}+\psi_{i} ; \quad i=1, \ldots, p
$$

Where:

$$
h_{i}^{2}=\operatorname{Var}\left(\sum_{j=1}^{k} a_{i j} F_{j}\right) \ldots, \ldots \psi_{i}=\operatorname{Var}\left(u_{i}\right)
$$

This equation corresponds to the communalities and the specificity of the variable $X_{i}$. Thus the variance of each variable can be divided into two parts: a) in their communalities $h_{i}^{2}$ representing the variance explained by common factors, and b) the specificity $\Psi_{I}$ that represents the specific variance of each variable.

Thus obtaining:

$$
\operatorname{Cov}\left(X_{i}, X_{l}\right)=\operatorname{Cov}\left(\sum_{j=1}^{k} a_{i j} F_{j}, \sum_{j=1}^{k} a_{l j} F_{j}\right)=\sum_{j=1}^{k} a_{i j} a_{l j} \forall i \neq 1
$$

With the transformation of the correlation matrix's determinants, we obtained Bartlett's Test of spherecity, and it is given by the following equation:

$$
d_{R}=-\left[n-1-\frac{1}{6}(2 p+5) \ln |R|\right]=-\left[n-\frac{2 p+11}{6}\right] \sum_{j=1}^{p} \log \left(\lambda_{j}\right)
$$


Where: $n=$ sample size, $\ln =$ natural logerithm, $\lambda_{j}(j=1, \ldots, p)$ values pertaingin to $R, R=$ correlation matrix.

Finally, as refer to García-Santillán et al. (2012) to compare the magnitude of the observed coefficients correlation with the magnitudes of the coefficients partial correlation is carried out by measuring the sample adequacy (KMO) proposed by Kaiser, Meyer and Olkin, and similar to the KMO index, the measure of sampling adequacy for each variable (MSA) can be calculated, in which it only includes the coefficients of the variable to be tested. Both measurements are given by the following expressions:

$$
K M O=\frac{\sum_{j \neq i} \sum_{i \neq j} r_{i j}^{2}}{\sum_{j \neq i} \sum_{i \neq j} r_{i j}^{2}+\sum_{j \neq i} \sum_{i \neq j} r_{i j(p)}^{2}} \quad M S A=\frac{\sum_{i \neq j} r_{i j}^{2}}{\sum_{i \neq j} r_{i j}^{2}+\sum_{i \neq j(p)} r_{i j}^{2}} ; i=1, \ldots, p
$$

Where: $r_{i j(p)}$ is the partial coeficient of the correlation between variables $X_{i}$ and $X_{j}$ in all the cases.

Finally, to compare the magnitude of the observed coefficients correlation with the magnitudes of the coefficients partial correlation is carried out by measuring the sample adequacy (KMO) proposed by Kaiser, Meyer and Olkin, and similar to the KMO index, the measure of sampling adequacy for each variable (MSA) can be calculated, in which it only includes the coefficients of the variable to be tested (op. cit.).

\section{Findings and Discussion}

The first illustration shows a descriptive analysis of the data. Table 3 shows the percentage of the participating universities, the percentage of gender and average age of respondents.

Table 3. Descriptive statistics

\begin{tabular}{lll}
\hline & Average age 22 years old & \\
& & Percentage \\
\hline Sex & Male & 49.0 \\
& Female & 51.0 \\
\hline University & Centro Universitario Hispano & \\
& Mexicano (CUHM) & 75.8 \\
& Escuela Superior de Negocios (ESUN) & 16.4 \\
& Instituto Tecnológico de Veracruz (ITV) & 7.8 \\
\hline
\end{tabular}

Factorial analysis results allow, first of all, notice that six out of the ten correlations are significant $(60 \%)$ at a significance level of 0.01 as shown in the following table, which indicates that the base is suitable for factor analysis.

Table 4. Correlation matrix

\begin{tabular}{llllll}
\hline Variable & Usefulness & Anxiety & Confidence & Likeness & Motivation \\
\hline Usefulness & 1.000 & $-0.125^{*}$ & $0.394^{*}$ & $0.383^{*}$ & -0.055 \\
Anxiety & & 1.000 & $-0.264^{*}$ & 0.029 & $0.367^{*}$ \\
Confidence & & 1.000 & $0.382^{*}$ & -0.049 \\
Likeness & & & 1.000 & 0.119 \\
Motivation & & & & 1.000 \\
\hline
\end{tabular}

* indicates significance level $(<0.01)$.

Table 5 shows the value of the Bartlett sphericity test (74.146) this value indicates that the correlation matrix is significant at a level of $(<0.001)$, thus meaning that the factor model is adequate to explain the data. In this case, the KMO value (0.600) allows us to confirm that it is appropriate to use factor analysis.

Table 5. KMO \& Bartlett's Test of sphericity

\begin{tabular}{lll}
\hline \multirow{3}{*}{ Bartlett test of sphericity } & Kaiser-Meyer-Olkin & 0.600 \\
& Chi-square aprox & 74.146 \\
& df & 10 \\
& Sig. & $(<0.001)$ \\
\hline
\end{tabular}


Another difference is the measure of sampling adequacy (MSA), the values shown in Table 6, reveals that each variable exceeds the threshold value of 0.5 , which indicates the strength of relationships between variables and therefore appropriateness factor analysis.

Table 6. Measure of sampling adequacy

\begin{tabular}{llllll}
\hline Variable & Usefulness & Anxiety & Confidence & Likeness & Motivation \\
\hline Usefulness & $0.673^{a}$ & & & & \\
Anxiety & 0.039 & $0.521^{a}$ & & & \\
Confidence & -0.262 & 0.260 & $0.624^{a}$ & & \\
Likeness & -0.285 & -0.105 & -0.296 & $0.613^{a}$ & \\
Motivation & 0.064 & -0.350 & -0.023 & -0.119 & $0.523^{a}$ \\
\hline
\end{tabular}

${ }^{a}$ Measure of sampling adequacy $>0.50$.

Table 7 shows the two factors and their contribution expressed by their eigenvalues (which must be greater than 1). The two factors account for $64.6 \%$ of the variance of the five variables.

Table 7. Extraction results of the components factor

\begin{tabular}{llll}
\hline Factor & Eigenvalue & \% variance & \% acumulated variance \\
\hline 1 & 1.840 & 36.805 & 36.805 \\
2 & 1.389 & 27.790 & 64.595 \\
\hline
\end{tabular}

Table 8 presents the load factor of each variable in each of the factors. The first factor that has been called conducive attitude to statistical variables consists of the usefulness $(0.758)$ confidence $(0.762)$ and likeness $(0.778)$, the second factor called improper attitude for statistics consists of variables anxiety $(0.812)$ and motivation $(0.812)$. Furthermore, the table provides the value of communalities, for example, the proportion of the variance can be explained by these two components. From this result, it was possible to identify that the variable usefulness is the least explained, the model is able to reproduce $58.3 \%$ of its original variability.

Table 8. Rotated estimated factors loadings and communalities

\begin{tabular}{llll}
\hline & \multicolumn{3}{c}{ Factors } \\
\hline Variables & 1 & 2 & Communalities \\
Usefulness & 0.758 & -0.097 & 0.583 \\
Anxiety & -0.168 & 0.812 & 0.688 \\
Confidence & 0.762 & -0.228 & 0.633 \\
Likeness & 0.778 & 0.235 & 0.660 \\
Motivation & 0.079 & 0.812 & 0.665 \\
& & & Total \\
Square sum (eigenvalue) & 1.794 & 1.435 & 3.230 \\
Percentage of variance & $36 \%$ & $29 \%$ & $65 \%$ \\
\hline
\end{tabular}

Table 8 reveals that the factors are in the order of their importance (1.794 and 1.435 respectively) and that $65 \%$ of the total variance is represented by the information contained in the factor matrix of the solution to the two factors. Therefore, the rate for this solution is adequate; the variables are in fact highly related to one another.

The factors that make up this structure, its variables have a statistical and practical significance, in other words, educational institutions may consider developing strategies to improve students' attitudes towards statistics and thus reduce the failure rate of students.

It should be noted, that the engineering students surveyed in this study are from a public university, which is generally characterized by having too much paperwork and bureaucratic procedures that impede the timely updating of their curricula. This bureaucratic environment does not allow a flexible reallocation from one subject to another teacher with more training or experience to teach the mentioned subject. This affects the quality of the classes that are taught. In addition, Overcrowding is another fact which makes difficult to keep monitoring students, so there 
is limited contact and attention from teachers and students. To this, we can partially add the fact that engineering students who come from a public university present a greater degree of anxiety and less confidence in statistics. By contrast, the students from the economic-administrative area studying in private universities, show greater interest in the teaching and development of the subject.

The results obtained agree with those proposed by Wise (1985) and Auzmendi (1992) that evaluated attitude from two perspectives: affective and cognitive; and the studies by Gil (1999) and Gómez-Chacón (2000) that highlighted the variable attitude, represented the thoughts, conceptions and beliefs about the attitude towards statistics.

\section{Conclusion}

The results of this research have corroborated the hypothesis that there is a set of variables that form a construct to understand the perception of students towards statistics. When students see the usefulness of this subject in their professional lives, they will enjoy the statistical work and therefore feel confident in their ability to use it as an instrument, however, when student's motivation is inadequate, there is fear for this discipline. If the participating universities were to study the elements of the second factor (improper attitude for statistics) and work for a certain time to compensate the negative attitude, students will improve their attitude towards statistics.

\section{Acknowledgements}

The authors are very gratefull with the annonimus peer-reviewer for all suggestions and the Cristóbal Colón University for all help and support. With our gratefull to Milka Escalera Chávez Ph.D., for all help and support.

\section{References}

Agne, K. J., Greenwood, G. E., \& Miller, L. D. (1994). Relationships between teacher belief systems and teacher effecteveness. The Journal of Research and Development in Education, 27(3), 141 -152.

Aparicio, A., \& Bazan, J. L. (1997). Actitudes hacia las matemática en ingresantes a la Universidad Nacional Agraria La Molina. Más Luz, Revista de Psicología y Pedagogía, 3(2), 351-380. Retrieved from http://argos.pucp.edu.pe/ jlbazan/download/ArticuloMasLuz.pdf

Aparicio, A., \& Bazán, J. (2006). Actitud y rendimiento en Estadística en profesores peruanos. En Acta Latinoamericana de Matemática Educativa, 19, 644-650. Clame 2005. Retrieved from http://www.ime.usp.br/ jbazan/download/ALME19.pdf

Aparicio, A., \& Bazán, J. (2008). Aspectos afectivos intervinientes en el aprendizaje de la estadística: actitudes y sus formas de evaluación. En Acta Latinoamericana de Matemática Educativa, 21, 180-189. Clame 2007. Retrieved from: http://www.clame.org.mx/documentos/alme21.pdf.

Auzmendi, E. (1991). Evaluación de las Actitudes hacia la Estadística en Estudiantes Universitarios y Factores que las determinan. Unpublished $\mathrm{PhD}$ thesis. Universidad de Deusto, Bilbao.

Auzmendi, E. (1992). Las actitudes hacia la matemática-estadística en las enseñanzas medias y universitarias. Bilbao, Mensajero.

Bazán, J. L., \& Aparicio, A. S. (2006). Las actitudes hacia la Matemática-Estadística dentro de un modelo de aprendizaje. Revista Semestral del Departamento de Educación, XV(28), Perú.

Behar, R., \& Grima, P. (2001). Mil y una dimensiones del aprendizaje de la estadistica. Estadística Española, 43(148), 189-207. Retrieved from: http://www.emis.de/journals/RCE/V34/v34n1a01.pdf

Bishop, A. (1996). International Handbook of Mathematical Education. Dordrecht Kluwer Academic Publishers.

Cashin, S. E., \& Elmore, P. B. (1997). Instruments used to assess attitudes toward statistics: A psychometric evaluation. Comunication presented at Annual Meeting of the American Educational Research Association, March, 1997 Chicago, IL, USA.

Cashin, S. E., \& Elmore, P. B. (2000). The Survey of Attitudes Toward Statistics scale: A construct validity study. Comunication presented at Annual Meeting of the Mid-Western Educational Research Association, October, 2000 Chicago, IL, USA.

Cashin, S. E. (2001). Effects of mathematics self-concept, perceived self-efficacy, and attitudes toward statistics on statistics achievement. Unpublished PhD thesis, Southern Illinois University, Carbondale, IL, USA.

Carmona, J. (2004). Una revisión de las evidencias de fiabilidad y validez de la cuestión de las actitudes y an- 
siedades hacia la estadística. Statistics Education Research Journal, 3(1), 5-28. Retrieved from http://www.stat.auckland.ac.nz/iase/serj/SERJ3(1)_marquez.pdf

Dillon, K. (1982). Sthatisticophobia. Teaching of Psycology, 117-131.

Dutton, W. (1954). Measuring attitudes toward arithmetic. The Elementary School Journal, 5, 24-31. Retrieved from http://www.jstor.org/discover/10.2307/999044?uid=3738664\&uid=2\&uid=4\&sid=21101114919897 http://dx.doi.org/10.1086/458640

Eagly, A. H., \& Chaiken, S. (1998). Attitude structure and function. In D. T. Gilbert, S. T. Fiske and G. Lindzey (Eds.), The handbook of social psychology, 4(1), 269-322. New York, NY, USA: McGraw-Hill.

Gal, I., \& Ginsburg, L. (1994). The role of beliefs and attitudes in learning statistics: towards an assessment framework. Journal of Statistics Education, 2(2). $\quad$ Retrieved from http://www.amstat.org/publications/jse/v2n2/gal.html

Gal, I., Ginsburg, L., \& Schau, C. (1997). Monitoring attitudes and beliefs in statistics education. In I. Gal y J. B. Garfield (Eds.), The assessment challenge in statistics education (pp. 37-51). Netherlands: IOS Press.

Gil, Flóres J. (1999). Actitudes hacia la estadística incidencia de las variables sexo y formación previa. Revista Española de Pedagogía, 214, 567-590.

García-Santillán, A., Flores, R., Escalera, M., Chong, I., \& López, S. (2012). Students, computers and mathematics. How do they interact in the teaching-learning process? Empirical study on accounting, management and marketing undergraduate students. International Journal of Learning and Development, 2(2), 177-200. http://dx.doi.org/10.5296/ijld.v2i2.1635

García-Santillán, A., Escalera, M., Boggero, P., \& Vela, J. (2012). Students' attitude toward Computer and Mathematics. Empirical study on Accounting, Management, Economy, International Commerce and Marketing undergraduate students. International Journal of Applied Science and Technology. 2(4), 1-11.

Gómez-Chacón, I. (2000). Matemática emocional. Los afectos en el aprendizaje matemático. Madrid: NARCEA, S. A, Ediciones.

Nasser, F. M. (2004). Structural model of the effects of cognitive and affective factor on the achievement of arabicspeakin pre-service teachers in introductory statistics. Journal of Satistics Education, 12(1). Retrieved from www.amstat.org/publications/jse/v12n1/nasser.html

Newcomb, T. M., Turner, R. H., \& Converse, P. E. (1965). Social Psychology: The Study of Human Interaction. New York: Holt, Rinehart and Winston.

Onwuegbuzie, A. J., DaRos, D., \& Ryan, J. M. (1997). The components of statistics anxiety: A phenomenological study. Focus on Learning Problems in Mathematics, 19(4), 11-35.

Onwuegbuzie, A. J. (1998). Teachers' attitudes toward statistics'. Psychological Reports, 83, 1008-1010. http://dx.doi.org/10.2466/pr0.1998.83.3.1008

Onwuegbuzie, A. J., \& Daley, C. E. (1999). Perfectionism and statistics anxiety. Personality and Individual Differences, 26, 1089-1102. http://dx.doi.org/10.1016/S0191-8869(98)00214-1

Onwuegbuzie, A. J., Slate, J. R., Paterson, F. R. A., Watson, M. H., \& Schwartz, R. A. (2000). Factors associated with achievement in educational research courses. Research in the Schools, 7(1), 53-65.

Onwuegbuzie, A. J., \& Wilson, V. A. (2003). Statistics anxiety: Nature, etiology, antecedents, effects, and treatments - A comprehensive review of the literature. Teaching in Higher Education, 8, 195-209. http://dx.doi.org/10.1080/1356251032000052447

Onwuegbuzie, A. J. (2003). Modeling statistics achievement among graduate students. Educational and Psychological Measurement, 63, 1020-1038. http://dx.doi.org/10.1177/0013164402250989

Phillips, R. (1993). Teacher attitude as related to student attitude and achievement in Elementary School Mathematics. School Science and Mathematics, 73(6), 501-507. http://dx.doi.org/10.1111/j.1949-8594.1973.tb09088.x

Roberts, D. M., \& Bilderback, E. W. (1980). Reliability and validity of a statistics attitude survey. Educational Psychological Measurement, 40, 235-238. http://dx.doi.org/10.1177/001316448004000138

Schau, C., Stevens, J., Dauphinee, T. L., \& Del Vecchio, A. (1995). The development and validation of the Survey 
of Attitudes Toward Statistics. Educational and Psychological Measurement, 55, 868-875. http://dx.doi.org/10.1177/0013164495055005022

Sheriff, C., Sheriff, M., \& Neberhall, R. (1965). Attitude and Attitude Change. Philadelphia: Saunders.

Watson, F., Kromrey, J., Ferron, J., Lang, T., \& Hogarty, K. (2003). An Assessment blueprint for encstat: A statistics anxiety intervention program. AERA anual meeting, San Diego.

Wise, Steven L. (1985). The development and validation of a scale measuring attitudes toward statistics. Educational and Psychological Measurement, 45(2), 401-405. 